Jakub Pokoj (Kraków)

\title{
Artykuł 58 Ordunku Górnego, czyli rzecz o początkach ubezpieczeń na Śląsku
}

\section{ZAGADNIENIA WSTĘPNE}

Ordunek Górny ${ }^{1}$ to uregulowanie prawa górniczego wydane w Opolu w listopadzie 1528 roku wspólnie przez Jana II z dynastii Piastów, księcia w Śląsku, na Opolu, Raciborzu i Głogówku, oraz Jerzego Hohenzollern-Ansbach, margrabiego brandenburskiego, księcia w Śląsku, na Karniowie i Raciborzu. Prawo górnicze, określone przez Stanisława Kutrzebę jako jedno spośród „praw specjalnych”, tj. praw odrębnych od ziemskiego i praw stanowych działu dawnego prawa, charakteryzujące się specyficznymi źródłami prawa, odpowiednimi dla „pewnych specjalnych stosunków"2. Dokument został wydany wspólnie przez Jana opolskiego i Jerzego brandenburskiego ze względu na szereg przywilejów i umów z lat 1507, 1512, 1522 i 1523, na mocy których Jerzy uzyskał prawo do spadku po Janie w przypadku jego bezpotomnej śmierci. Nadto Hohenzollern w roku 1523 został formalnie uznany za księcia śląskiego, zaś w 1524 nabył państwo bytomskie ${ }^{3}$.

${ }^{1}$ Niem. Bergordnung für Fürstenthümer Oppeln, Ratibor und Jägerndorf, die Herrschaft Beuthen (pol. Ordynacja górnicza dla księstw opolskiego, raciborskiego i karniowskiego, państwa bytomskiego). Choć wydaje się, że najpoprawniejsze thumaczenie nazwy tej ustawy powinno brzmieć po prostu „ordynacja górnicza”, to jednak od czasu publikacji Józefa Piernikarczyka (J. Piernikarczyk, Pierwsza polska ustawa górnicza czyli „, Ordunek Gorny”. Historyczny dokument Górnego Ślaska z roku 1528, Tarnowskie Góry 1928) ordynację górniczą Jana II opolskiego i Jerzego Hohenzollerna w literaturze polskojęzycznej zwykło się określać mianem „Ordunku Górnego”.

2 S. Kutrzeba, Historja źródel dawnego prawa polskiego, t. II, Lwów - Warszawa - Kraków, 1926, s. 333. Obok prawa górniczego, do kategorii praw specjalnych Stanisław Kutrzeba zaliczył także: prawo wojskowe, prawo lenne, prawo bartnicze, prawo wekslowe, prawo autorskie, prawo ordynackie oraz prawo uniwersyteckie.

${ }^{3}$ A. Kamieński, Sprawa sukcesji Hohenzollernów brandenburskich na Górnym Ślasku w epoce wczesnonowożytnej (do 1740 roku), „Czasy Nowożytne” 2009, t. 22, s. 63. 
Niestety, dotychczas brak prac naukowych poświęconych wyłącznie regulacji art. 58 omawianej ordynacji w kontekście źródeł prawa ubezpieczeń. Mając na względzie rozwój badań nad historią prawa ubezpieczeń w Europie Zachodniej, gdzie dawne urządzenia prawne są analizowane pod kątem ich rozwoju i wykształcania się znanych dzisiaj instytucji prawa ubezpieczeń ${ }^{4}$, podjęcie tematyki na gruncie pomnika prawa górniczego, jakim niewątpliwie jest Ordunek Górny, wydaje się ze wszech miar uzasadnione. Jak wskazano wcześniej, dotychczas art. 58 nie był przedmiotem pogłębionych badań z perspektywy prawnoubezpieczeniowej. Zazwyczaj wzmiankowany jest, niekoniecznie w sposób prawidłowy, jako „namiastka opieki socjalnej”, źródło normatywne systemu ubezpieczeń przymusowych górników ${ }^{6}$ czy nawet jako przedkapitalistyczne narzędzie wyzysku robotników ${ }^{7}$. Niniejsze opracowanie ma na celu zbadanie przedmiotowej regulacji w kontekście źródeł prawa ubezpieczeń.

Zaznaczyć przy tym należy, iż niniejszy artykuł nie aspiruje do roli kompleksowego omówienia Ordunku Górnego jako źródła prawa, lecz jedynie wąskiego jego wyimku, który, jak się wydaje, mógł statuować konstrukcję przypominającą ubezpieczenia w dzisiejszym rozumieniu. We wstępnej części artykułu zawarto jednak podstawowe informacje poświęcone zarówno samemu Ordunkowi (w tym najważniejszą literaturę przedmiotu), jak i prawu górniczemu.

Problematyka prawa górniczego jest ściśle związana z kwestią regale górniczego, czy też szerzej - materii regaliów. Jak wskazuje się w literaturze przedmiotu regalia to „zastrzeżone wyłącznie dla monarchy prawa gospodarcze, które pozwalały mu na rozwijanie działalności gospodarczej w określonych dziedzinach na zasadzie monopolu, co prowadziło do ograniczenia prawa własności prywatnej"». Precyzując wskazać należy, iż regale górnicze to takie ograniczenie prawa własności, które zastrzega dla władcy wyłączne prawo do poszukiwania i wydobywania kopalin, sprowadzające się do zasady, że wszystko, co znajduje się w ziemi poniżej pewnego poziomu (np. głębiej niż sięgał pług - tak w Zwierciadle Saskim $^{9}$ ) należy do panującego ${ }^{10}$. Regale górnicze przysługiwało co do za-

${ }^{4}$ P. Hellwege, A comparative history of insurance law in Europe, „American Journal of Legal History" 2016, z. 1, s. 70-71.

${ }^{5}$ A. Przybyłka, Świadczenia emerytalne zwiazane z praca $w$ górnictwie na przestrzeni dziejów, „Studia Ekonomiczne. Zeszyty Naukowe Uniwersytetu Ekonomicznego w Katowicach”, nr 258/2016, s. 222.

${ }^{6}$ A. Kolek, Budowa wspólnoty finansowej na podstawie islamskiej koncepcji ubezpieczenia „,Takaful”, https://depot.ceon.pl/handle/123456789/3309 [dostęp: 17.09.2016].

${ }^{7}$ D. Molenda, Górnictwo kruszcowe na terenie złóż ślasko-krakowskich do połowy XVI wieku, Wrocław - Warszawa - Kraków 1963, s. 319.

8 S. Płaza, Historia prawa w Polsce na tle porównawczym, t. 1, Kraków 1997, s. 279.

9 Z. Filipiak, A. Gaca, Prawo własności nieruchomości w obliczu regulacji prawa górniczego w Królestwie Polskim z 1817 i 1870 roku, „Studia Iuridica Toruniensa”, t. X, s. 246.

${ }^{10}$ T. Dziekoński, Wydobywanie i metalurgia kruszców na Dolnym Śląsku od XIII do połowy XX wieku, Wrocław 1972, s. 18. 
sady monarsze i było związane z oddzieleniem prawa do użytkowania powierzchni gruntu i czerpania z niej pożytków od prawa do poszukiwania i pozyskiwania kopalin z wnętrza ziemi, w myśl koncepcji tzw. własności podzielonej ${ }^{11}$, w szczególności zaś dominującej na Górnym Śląsku własności alodialnej ${ }^{12}$.

Prawo do poszukiwania i wydobywania kopalin, jak wskazano wyżej, posiadał monarcha. Podobnie jak inne regale o charakterze gospodarczym, np. regale łowieckie, panujący mógł je przenieść na inne podmioty. I tak na przykład klasztor benedyktynów tynieckich już przed 1105 rokiem otrzymał prawo do prowadzenia eksploatacji górniczej na należących do niego terenach ${ }^{13}$. Jeśli jednak nie zastrzeżono inaczej (np. w przywileju lokacyjnym dla klasztoru), to prawo do poszukiwania i wydobywania kopalin było przynależne władcy. Wskazać należy, iż pomimo lennej zależności od króla czeskiego, zarówno Jan, jak i Jerzy dysponowali regale górniczym. Posiadając prawo do prowadzenia eksploatacji górniczej obaj książęta mogli wydać regulację normującą działalność górniczą na ich ziemiach. Jak wskazuje się w literaturze przedmiotu „książęta śląscy z chwilą złożenia hołdu odbierali od króla posiadane dotychczas regalia, zwyczajowo przysługujące książętom. Stanowiły je poręczenia autonomii wewnętrznej księstwa, zwierzchnictwa lennego, wyłączności stanowienia instancji sądowej, regale górniczego, łowieckiego, menniczego oraz tradycyjnie niezależność prowadzenia polityki dynastycznej"14.

Występujący w intytulacji omawianego dokumentu Jan i Jerzy wydając ordynację górniczą wykonywali swoje prawa, na co może wskazywać charakterystyczna formuła „oznajmiamy i czynimy” (niem. bekennen und kund thun). Wystawcy dokumentu nie uzależniają wejścia w życie przewidzianych w nim regulacji od otrzymania sankcji swojego suwerena. Stąd też przyjąć należy, iż wydając ordynację górniczą obaj prawodawcy korzystali z przysługującego im regale górniczego.

Wydanie Ordunku należy wiązać w szczególności z nabyciem przez Hohenzollerna państwa bytomskiego, gdyż przedmiotowa ordynacja miała w głównej mierze przyczynić się do poprawy nie najlepszej kondycji górnictwa kruszcowego w okolicach Bytomia bądź zgoła zapoczątkowania eksploatacji złóż nowo

${ }_{11}$ Por. H. Kupiszewski, Rozważania o własności rzymskiej, „Czasopismo Prawno-Historyczne" 1984, t. 36, nr 2, s. 64.

${ }_{12}$ M.J. Ptak, Własność alodialna i lenna na Ślasku [w:] A. Barciak (red.), Kultura prawna w Europie Środkowej, Katowice 2006, s. 102.

13 E. Nych, Własność złóż kopalin, „Materiały XIII Warsztatów Górniczych z cyklu »Zagrożenia naturalne w górnictwie«", 2009, s. 258.

14 J. Kuczer, Szlachta w życiu społeczno-gospodarczym księstwa głogowskiego w epoce habsburskiej 1526-1740, Zielona Góra 2007, s. 26; por. także K. Orzechowski, Historia ustroju Ślaska 1202-1740, Wrocław 2005, s. 74 oraz K. Wutke, Studien über die Entwicklung des Bergregals in Schlesien, Berlin 1897, s. 160-162. 
odkrytych, w szczególności w okolicach dzisiejszych Tarnowskich Gór ${ }^{15}$. Początków górnictwa kruszcowego w okolicach Bytomia należy doszukiwać się jednak w XII wieku bądź nawet wcześniej, gdyż już dwunastowieczne źródła pisane potwierdzają prowadzenie w ziemi bytomskiej wydobycia, głównie srebra i ołowiu ${ }^{16}$. Wobec stopniowego wyczerpywania się złóż położonych bliżej Bytomia na początku XVI stulecia eksploatacja górnicza zaczęła intensyfikować się w okolicach późniejszych Tarnowskich Gór. W XVI wieku wokół Tarnowskich Gór znajdowało się już przeszło 20000 nowych szybów górniczych, podczas gdy wcześniej było ich niespełna $1300^{17}$. Górnictwo kruszcowe w okolicach Tarnowskich Gór rozwijało się dynamicznie aż do około połowy XVI wieku, kiedy to w następstwie obniżenia opłacalności działalności górniczej, wynikającej głównie z napływu kruszców z Ameryki i wzrostu kosztów działalności dotychczas eksploatowanych złóż, produkcja uległa osłabieniu ${ }^{18}$.

Historia ordynacji z 1528 roku jest ściśle związana z Tarnowskimi Górami, nie tylko ze względu na prowadzenie eksploatacji górniczej wokół tej miejscowości, ale także ze względów prawnych. W roku 1526 Jan II Opolski wydał dokument określany jako „wolność górnicza” ${ }^{19}$, nadający szereg przywilejów górnikom. Przypuszczalnie jeszcze w 1526 roku Tarnowskim Górom zostały nadane prawa miejskie i co za tym idzie, na rok 1526 należy datować powstanie tarnogórskiej rady miejskiej ${ }^{20}$. Tarnowskie Góry stały się wówczas osobą prawną o charakterze korporacyjnym ${ }^{21}$. Wolność górnicza została następnie odnowiona 20 października 1599 roku. Ze względu na wydanie wolności górniczej Tarnowskie Góry uzyskały status tzw. „wolnego miasta górniczego"22. Kwestia ta jest o tyle istotna, że zgodnie z regulacją Ordunku tarnogórska rada miejska odgrywała istotną rolę przy wydatkowaniu środków zgromadzonych w kasie brackiej, o czym będzie mowa poniżej. Podkreślić należy również, iż w omawianej ordynacji zostały zawarte także regulacje poświęcone prawom i obowiązkom mieszkańców wolnego miasta

15 D. Molenda, Górnictwo kruszcowe..., s. 192.

16 W. Korta, Historia Ślaska do 1763 roku, Warszawa 2003, s. 205.

17 E. Maleczyńska, $i$ hutnictwo [w:] K. Maleczyński (red.), Historia Śląska, t. I do roku 1763, cz. II od połowy XIV do trzeciej ćwierci XVI w., Wrocław - Warszawa - Kraków 1961, s. 105.

18 J. Gierowski, Epoka feudalna [w:] K. Maleczyński (red.), Historia Śląska, t. I do roku 1763, cz. III od końca XVI w. do r. 1763, Wrocław - Warszawa - Kraków, s. 221; por. także Memoriat w sprawie kopalnictwa rud ołowiu i srebra na Górnym Ślasku, Katowice 1957, s. 22-24.

${ }_{19}$ Niem. Bergfreiheit.

${ }^{20}$ Por. J. Piernikarczyk, Historia miasta Tarnowskie Góry 1526-1926, Tarnowskie Góry 1926. s. 51

${ }_{21}$ M.J. Ptak, Położenie prawno-polityczne miast ślaskich $w$ czasach nowożytnych. Wybrane zagadnienia [w:] I. Panic (red.), Samorzadowość i elity władzy w Cieszynie na przestrzeni dziejów, Cieszyn 2002, s. 27.

${ }^{22}$ Cz. Piernikarczyk, Tarnowskie Góry. Historia miasta i górnictwa w zarysie, Katowice 1991, s. 6. 
górniczego, np. w art. 49 dotyczącym wymogów stawianych burmistrzom oraz składu etnicznego rady miejskiej ${ }^{23}$. Dodatkowo potwierdza to istotny związek pomiędzy omawianym dokumentem a miastem Tarnowskie Góry i jego wczesnonowożytnym statusem ${ }^{24}$.

Tekst normatywny został skonstruowany w sposób dość jasny, bowiem został on podzielony na 72 jednostki redakcyjne. Co do zasady można przyjąć, że Ordunek regulował materię prawa górniczego w sposób całościowy, choć na mocy artykułu pierwszego pozwalał na subsydiarne stosowanie zwyczajów, pod warunkiem ich zgodności z prawem (legalności). Jeśli chodzi o wymóg zgodności z prawem zwyczaju można wysnuć trzy wnioski: 1) zwyczaj górniczy nie mógł stać w sprzeczności z normami prawa stanowionego ( $\mathrm{tj}$. przede wszystkim ordynacji górniczej, ale także wolności górniczej z 1526 oraz wielkiego przywileju ziemskiego z 1531 roku $^{25}$ ); 2) zwyczaj górniczy winien był być zgodny z prawem naturalnym oraz 3 ) z prawem Bożym ${ }^{26}$. Zgodnie bowiem prawem kanonicznym, „istniejący zwyczaj nie mógł uchylić norm prawa naturalnego i Bożego, jak również powinien być (jak cały system prawny) zgodny z normami religijnymi i tym samym służyć jako narzędzie wiodące do zbawienia"27.

Ordunek Górny, jak się wydaje, był dość udany pod względem poprawności legislacyjnej, skoro ordynacja ta, po odnowieniu dnia 20 października $1599 \mathrm{roku}^{28}$, obowiązywała aż do czasów pruskich. Zakres temporalny obowiązywania omawianej regulacji zakończył dzień 5 czerwca 1769 roku, kiedy to Fryderyk II Wielki wprowadził nową ordynację górniczą dla całego obszaru pruskiego Śląska. Ordynacja z 1528 roku została zresztą wzmiankowana we fryderycjańskiej regulacji jako jedna z uchylanych regulacji ${ }^{29}$. Jeśli zaś chodzi o zakres terytorialny stosowania Ordunku to, jak wynika zarówno z samego

${ }^{23}$ Wśród innych regulacji Ordunku związanych bezpośrednio z Tarnowskimi Górami wskazać należy na sprawy bezpieczeństwa i porządku publicznego, wskazane w art. 53.

${ }^{24}$ D. Szlachcic-Dudzicz, Tarnowskie Góry. Geneza i najstarsze dzieje górniczego miasta, Warszawa 2006, s. 50.

${ }_{25}$ Por. M.J. Ptak, Sąd ziemski Księstwa Opolsko-Raciborskiego w świetle przywileju z 1531 roku [w:] A. Konieczny (red.), Studia historycznoprawne: tom poświęcony pamięci Profesora Edwarda Szymoszka, Wrocław 2008, s. 303-312.

26 J. Pokoj, Ordunek Górny z perspektywy historycznoprawnej [w:] S. Duży (red.), Ochrona środowiska na terenach górniczych i pogórniczych kopalń w Subregionie Zachodnim Województwa Śląskiego, Rybnik 2016, s. 160.

${ }_{27}$ G.M. Kowalski, Zwyczaj i prawo zwyczajowe w doktrynie prawa i praktyce sądów miejskich karnych w Polsce (XVI-XVIII w.), Kraków 2013, s. 44.

28 A. Steinbeck, Entwurf einer Geschichte der Schlesischen Bergwerks-Verfassung vor dem Jahre 1740, Berlin 1827, s. 113.

${ }^{29}$ Revidirte Bergordnung vor das souveraine Herzogtum Schlesien und die Grafschaft Glatz vom 5. Juni 1769, Breslau 1857, s. 1. 
tytułu ordynacji, jak i z art. 1, obowiązywała ona w księstwach opolskim, raciborskim, karniowskim oraz w państwie bytomskim.

Do czasów współczesnych nie zachował się oryginał Ordunku. Najpopularniejszy współcześnie jego tekst został opublikowany przez Konrada Wutkego w tomie XX Śląskiego Kodeksu Dyplomatycznego (Codex Diplomaticus Silesiae) $)^{30}$. Jak podaje Zdzisław Jedynak, tekst wydany przez Wutkego został zaczerpnięty z egzemplarza spisanego w Karniowie przed radą miejską i burmistrzem, którzy potwierdzili, że przedstawiono im dokument o podanej treści ${ }^{31}$. Egzemplarz z 1558 roku miał zatem charakter widymatu (transumptu) ${ }^{32}$. Wydaje się, że tekst ordynacji wydany przez Wutkego jest kompletny i wiernie odzwierciedla oryginał dokumentu, tym bardziej, że tekst ten jest zbieżny z edycją Ordunku opublikowaną w 1791 roku przez Thomasa Wagnera ${ }^{33}$. Edycja widymatu opublikowanego w ramach Śląskiego Kodeksu Dyplomatycznego pozostaje zatem najlepiej znanym źródłem poznania przedmiotowej ordynacji.

Do literatury polskojęzycznej termin „Ordunek Górny” wprowadził Józef Piernikarczyk, wydając w 1928 roku swoją publikację zatytułowaną: Pierwsza polska ustawa górnicza czyli „Ordunek Gorny”. Historyczny dokument Górnego Śląska z roku $1528^{34}$. Znacząco mijając się z faktami, Piernikarczyk we wstępie do tegoż opracowania wskazał, że ,przedziwny zbieg okoliczności tak zdziałał, że właśnie tuż przed upływem 4-ro wiekowego istnienia ustawy górniczej zdołałem odkryć ten klasyczny pomnik polskiego ustawodawstwa górniczego"35. Obecnie nie ulega już jednak wątpliwości, że Piernikarczyk odnalazł jedynie osiemnastowieczny polskojęzyczny wypis z szesnastowiecznego dokumentu ${ }^{36}$. Niemniej jednak niewątpliwą zasługą Piernikarczyka jest swoiste „,wypromowanie” szesnastowiecznej śląskiej ordynacji górniczej i zaprezentowanie jej wydania szerokiemu gronu odbiorców. Niestety, polskojęzyczny wypis z ordynacji sporządzony i wydany przez Piernikarczyka częstokroć pomija istotne badawczo fragmenty tekstu normatywnego - także w przypadku art. 58.

Dokonując zestawienia dotychczasowych publikacji poświęconych problematyce Ordunku, odnotować należy także inną pracę autorstwa Piernikarczyka, Historię górnictwa i hutnictwa na Górnym Śląsku ${ }^{37}$, w której tomie drugim znajduje się fragment poświęcony przedmiotowej ordynacji. Wymienić należy także publikację Eugeniusza

${ }^{30}$ Codex Diplomaticus Silesiae, t. XX, red. K. Wutke, Breslau 1900, poz. 427, s. 244-263.

${ }^{31}$ Z. Jedynak, Ordunek Gorny, „Montes Tarnovicensis” 2002, nr 10.

32 Por. S. Kętrzyński, Zarys nauki o dokumencie polskim wieków średnich, Poznań 2008, s. 66.

${ }_{33}$ T. Wagner, Corpus iuris metallici recentissimi et antiquioris, Leipzig 1791, s. 1275-1298.

${ }^{34}$ J. Piernikarczyk, Pierwsza polska ustawa...

${ }^{35}$ Ibidem, s. 3.

${ }^{36}$ Z. Jedynak, Ordunek Gorny...

37 J. Piernikarczyk, Historia górnictwa i hutnictwa na Górnym Śląsku, t. 1 Katowice 1933 i t. 2 Katowice 1936. 
Kobzdaja pt.: Ordunek gorny - ustawa górnicza dla Górnego Śląska z 1528 r. ${ }^{38}$ Jest to edycja źródłowa polskiego wypisu opublikowanego wcześniej przez Piernikarczyka. Na szczególną uwagę zasługują w nim jednak wstęp merytoryczny oraz słowniczek. Wskazać należy także na kilkudziesięciostronicowe wprowadzenie merytoryczne autorstwa Roberta Wilhelma Borowego, poprzedzające reprint polskojęzycznego wypisu z tekstu Ordunku, opublikowanego wcześniej przez Piernikarczyka ${ }^{39}$. Bardzo cenne uwagi i spostrzeżenia dotyczące omawianej ordynacji oraz jej późniejszych odpisów zostały natomiast opublikowane przez Zdzisława Jedynaka ${ }^{40}$. Ordynacja ta była także przedmiotem rozważań z perspektywy historycznoprawnej ${ }^{41}$. Szerszą bibliografię dotyczącą historii górnictwa na Śląsku według stanu na początek lat sześćdziesiątych XX wieku zaprezentowała Ewa Maleczyńska ${ }^{42}$.

Źródłem omawianego zwodu prawa górniczego w znaczeniu materialnym były polskie prawidłowe (zgodne z prawem) zwyczaje górnicze, stanowiony frankoński porządek i prawo górnicze oraz zwyczaje górnicze funkcjonujące w ziemi bytomskiej. Jeśli chodzi o zwyczaje, to powtórzyć należy, iż wymóg zgodności z prawem należy rozumieć jako ich zgodność z prawem stanowionym, prawem naturalnym oraz prawem Bożym.

W odniesieniu do polskich zwyczajów górniczych podkreślić należy, iż w literaturze przedmiotu wskazuje się, że Ordunek miał być wzorowany na prawie górniczym kopalń olkuskich. Jak się jednak wydaje, w treści omawianej ordynacji brak jest uzasadnienia dla tezy, jakoby „ordynacja ta [Ordunek Górny - J.P.], bardzo szczegółowa, liczyła 72 paragrafy i opierała się na prawie czeskim oraz na polskim prawie górniczym kopalń olkuskich" ${ }^{33}$. Potwierdzenia dla tej tezy nie dostarcza ani tekst dokumentu, w szczególności zaś miarodajne w tym zakresie intytulacja oraz artykuł pierwszy, ani badania historyków - zarówno te dawniejsze ${ }^{44}$, jak i now$\mathrm{sze}^{45}$. Ze względu jednak na znaczną liczbę ordynacji dla kopalń olkuskich poprze-

${ }^{38}$ E. Kobzdaj, Ordunek gorny - ustawa górnicza dla Górnego Śląska z 1528 r., Wrocław Warszawa - Kraków 1990.

39 R.W. Borowy, Ordunek gorny - edycja krytyczna. Wolność górnicza - 1526 r. Ordunek gorny z 1528 roku [w:] J. Mańka (red.), Poczet Gwarków Śląskich, z. 4, Katowice 2011, s. 12-35.

${ }^{40}$ Z. Jedynak, Ordunek Gorny...

${ }^{41}$ J. Pokoj, Ordunek Górny..., s. 156-162.

${ }^{42}$ E. Maleczyńska, Górnictwo..., s. 100.

43 J. Bardach (red.), Historia państwa i prawa Polski, tom II od połowy XV wieku do r. 1795, wyd. IV, Warszawa 1971, s. 67.

${ }^{44}$ Por. J. Piernikarczyk, Historia ..., t. 2, s. 230-232. Józef Piernikarczyk podawał, że w konsekwencji zasadniczo jednolitych prawideł technicznych działalności górniczej oraz migracji górników „przeszczepianie praw (...) było ułatwione” (ibidem, s. 231). Konstatacja ta wydaje się o tyle słuszna, że wskutek migracji górników pewnemu ujednoliceniu ulegać mogły także zwyczaje górnicze.

${ }^{45} \mathrm{~W}$ swoich ustaleniach Józef Piotrowicz wskazywał wprost przeciwnie - to regulacje Ordunku Górnego miały być wzorem dla gwarków olkuskich, którzy powołując się na jego zapisy mieli żądać rozszerzenia swoich praw górniczych. Por. J. Piotrowicz, Ordynacja górnicza dla Górnego 
dzających wydanie Ordunku ${ }^{46}$, nie można wykluczyć, że prawodawcy w określonym zakresie mogli się wzorować także na ordynacjach olkuskich. W najstarszym przywileju dotyczącym olkuskich kopalń, wydanym przez Elżbietę Łokietkównę w 1374 roku, podobnie jak w Ordunku wskazano, że prawo do działalności górniczej znajduje oparcie w „dawnych zwyczajach" ${ }^{\text {47 }}$. Próbując doszukiwać się związków między regulacjami dotyczącymi kopalń olkuskich i tych leżących w ziemiach należących do Jana i Jerzego należałoby raczej dojść do przekonania, że jedyna analogia zachodząca między nimi, którą można potwierdzić z pewnością, to fakt, iż w obu przypadkach regulacje prawa stanowionego opierały się, przynajmniej częściowo, na lokalnych zwyczajach. Należy jednak podkreślić, iż piętnastowieczni górnicy, w szczególności specjaliści, stanowili jak na owe czasy grupę dość mobilną ${ }^{48}$. W związku z tym prawdopodobne wydaje się przenikanie nie tylko technologii, ale także zwyczajów oraz uregulowań prawa pozytywnego, przynoszonych do poszczególnych ośrodków górniczych przez wędrujących górników.

Jeśli zaś chodzi o „prawo czeskie” to niewątpliwie autor miał na myśli wpływy prawa igławskiego, także wskazywanego w literaturze jako jedno ze źródeł regulacji zawartych $\mathrm{w}$ omawianej ordynacji ${ }^{49}$. Podobnie $\mathrm{w}$ tym przypadku argumentem mogącym przemawiać za wpływem prawa igławskiego na ordynację z 1528 roku może być fakt rozpowszechnienia tej regulacji. Prawo igławskie to zwód zwyczajowego prawa górniczego, spisany w morawskiej Igławie ok. 1248 $\mathrm{roku}^{50}$. W literaturze ugruntowany jest pogląd o silnym wpływie prawa igławskiego na prawo górnicze na Śląsku, m.in. poprzez odwoływanie się przez śląskich górników do ławników igławskich w kwestiach spornych ${ }^{51}$. W szczególności podkreślenia wymaga okoliczność, iż prawo igławskie to zbiór zwyczajowego prawa górniczego ${ }^{52}$. Korzyści wypływające ze spisania zwyczajowego prawa górniczego mogły być inspiracją dla twórców Ordunku, stanowiącego przynajmniej częściowo odzwierciedlenie zwyczajów górniczych.

Sposób odwołania się do unormowań frankońskich wskazuje, że miały one służyć raczej jako wzorzec dla ewentualnego zrewidowania wybranych zwycza-

Śląska z 1528 r. a dawne ustawodawstwo małopolskiego górnictwa solnego, „Studia i materiały z dziejów żup solnych w Polsce" 1980, t. 9, s. 205.

46 Z lat: $1374,1426,1485,1491,1492-1501$ oraz 1505.

${ }^{47}$ H. Labęcki, Górnictwo w Polsce. Opis kopalnictwa i hutnictwa polskiego pod względem technicznym, historyczno-statystycznym i prawnym, t. 1, Warszawa 1841, s. 190.

${ }^{48}$ Ibidem, s. $108-110$

49 E. Maleczyńska, Górnictwo..., s. 114.

${ }^{50}$ R. Adler, Poczatki nadzoru górniczego, „Nowy Górnik” 2013, nr 2, s. 4.

${ }^{51}$ F. Skibiński, Regale górnicze we wczesnem średniowieczu na Zachodzie i w Polsce, „Przegląd Historyczny" 1929, nr 28/2, s. 213.

52 J. Majer, Rudné hornictví v Čechách, na Moravě a ve Slezsku: obrazy z dějin těžby a zpracování, Praha 2004, s. 55. 
jów niż jako regulacje mające być wprost transponowane do śląskiego porządku normatywnego (,jako ustanowił [Jerzy Hohenzollern-Ansbach - J.P.] w swoich umiłowanych kopalniach we Frankonii" ${ }^{53}$ ). Wzorcem miał być frankoński porządek górniczy i prawo, a więc zarówno zwyczaje, jak i prawo stanowione. Jeśli zaś chodzi o zwyczaje górnicze w ziemi bytomskiej, to w trzeciej dekadzie XVI wieku górnictwo górnośląskie miało już za sobą kilkuwiekową tradycję. Dowodzi tego choćby fakt, że już w XIII wieku Krzyżacy sięgnęli po śląskie prawo górnicze jako wzorzec dla swoich uregulowań ${ }^{54}$. Konstatacja ta, jak się wydaje, ma niebagatelne znaczenie dla oceny charakterystyki regulacji zawartych $\mathrm{w}$ ordynacji. W intytulacji tegoż dokumentu zawarto bowiem znamienną deklarację, wedle której ordynacja została wydana, „by móc prawnie utrzymać dobry porządek [ordunek]”"55.

W artykule pierwszym prawodawca wskazał natomiast, że „szczególny porządek górniczy i prawo uległy zapomnieniu" ${ }^{\text {, }}$, co tym bardziej powinno skłaniać ku poglądowi, że na długo przed wydaniem omawianej ordynacji górniczej śląskie górnictwo zdążyło wytworzyć zwyczaje regulujące ogół działalności w zakresie wydobywania kopalin. W konsekwencji należy uznać, iż zrąb regulacji Ordunku stanowiły zwyczaje górnicze funkcjonujące $\mathrm{w}$ rejonie Bytomia, zaś intencją prawodawców w osobach Jana i Jerzego było podtrzymanie i być może częściowe zrewidowanie zwyczajów, które powoli ulegały zapomnieniu wskutek porzucenia dawnego górnictwa ${ }^{57}$.

Nadanie owym zwyczajom przymiotu prawa stanowionego, co zostało uczynione dzięki wydaniu Ordunku, miało z pewnością walor wzmacniający regulacje obowiązujące dotychczas w sposób niesformalizowany. Praktyka formułowania ordynacji górniczych jako spisu zwyczajów, zrewidowanych i uzupełnionych jednak zgodnie z wolą prawodawcy, występowała już wcześniej. Ilustracyjnie wskazać można na przykład ordynacji żupnej Kazimierza Wielkiego z 1368 roku dla żup krakowskich w Wieliczce i Bochni. Jak wskazał Stanisław Kutrzeba, ordynacja ta została sporządzona jako świadectwo zwyczajów przestrzeganych w żupach, jednakże „pomimo zapewnień, w niej zawartych, iż tylko dawne zwyczaje się spisuje, widać, iż przeprowadzono przy tej sposobności szereg reform" ${ }^{58}$. W odniesieniu do Ordunku nie można jednak uznać, że stanowi on jedynie spis funkcjonujących zwyczajów, zrewidowany przy okazji ich spisywania, skoro prawodawcy wprost wymienili dwa inne, formalnie równorzędne źródła prawa w znaczeniu materialnym.

\footnotetext{
53 Niem. so uber seiner lieb bergwerk in Franken gestellt (art. 1).

54 H. Łabęcki, Górnictwo..., s. 103.

55 Niem. mit rechtmessiger guter ordnung wiss zu halten (intytulacja).

56 Niem. die sonderlich bergordnung und recht aus gedechtniss kommen seyn (art. 1).

57 Niem. aus abfall der alten bergwerk (art. 1).

58 S. Kutrzeba, Historja..., s. 334.
} 
Wskazać należy, iż w literaturze niemieckiej dominuje pogląd, zgodnie z którym równorzędnymi źródłami regulacji zawartych w Ordunku, były polskie zwyczaje górnicze oraz normy stanowionego frankońskiego prawa górniczego ${ }^{59}$.

\section{JEZYK I TEKST NORMATYWNY}

Obecnie nie ulega już wątpliwości, że w oryginale Ordunek został sporządzony w języku niemieckim ${ }^{60}$. W tymże języku ordynacja została wydana także przez Wutkego. Mając na względzie, że dokument $w$ oryginale został sporządzony w języku niemieckim, jak również fakt, że przynajmniej częściowo opierał się on o wzorce pochodzące $\mathrm{z}$ frankońskiego prawa górniczego, zasadne wydaje się poszukiwanie znaczenia treści poszczególnych norm czy instytucji prawa górniczego właśnie w źródłach niemieckich. Nawet bowiem przyjmując, że określone regulacje Ordunku opierały się na zwyczajach górniczych, to jednak fakt, że przybrały one ramy prawa stanowionego spisanego w języku niemieckim spowodował, że zastosowano wobec nich niemiecką terminologię górniczą. Stąd też interpretując poszczególne sformułowania w dalszej części artykułu posługiwano się w pierwszym rzędzie definicjami zawartymi w niemieckich wydawnictwach fachowych.

Analizę normatywnych założeń konstrukcji opisanej w art. 58, jak się wydaje, powinno poprzedzić zbadanie tekstu tegoż przepisu. W tym celu poniżej przedstawiono tekst oryginalny art. 58. (wg edycji Wutkego zawartej w tomie XX CDS), tekst polskiego wypisu za edycją Kobzdaja oraz tłumaczenie własne autora (wg edycji Wutkego zawartej w tomie XX CDS).

\section{Der 58. Artikel}

Wie all sunabent schichtmeister oder huttleute wescher röster lehenheuer allerlei schaffer, die unter sich arbeiter haben, von iedem 2 heller soll nemen.

All wuchen im sonabent sollen schichtmeister huttenleut lehenheuer wescher röster, die da arbeiter unter irer verwaltung haben, in der ablonung von ieglichem arbeiter 2 heller einnemen und in ein verschlossene lad oder buchs bei dem berckmeister einlegen, darzu er und der rat ieglicher ein schlussel haben soll, und solch geld zu erhaltung der armen kranken gesellen und andern gemeinen nutz anwenden und alle quatember oder wenn es die zeit erfordert, unserm berckhauptmann berckmeister und ratleuten davon rechnung tuen ${ }^{61}$.

59 C.J.B. Karsten, Archiv für bergbau und hüttenwesen, Berlin 1827, s. 337.

${ }^{60}$ Por. ustalenia wrocławskiego archiwisty Derscha zawarte w liście do bytomskiego radcy Immerwahra [w:] R.W. Borowy, Ordunek gorny - edycja krytyczna. Wolność górnicza - 1526 r. Ordunek gorny z 1528 roku [w:] J. Mańka (red.), Poczet Gwarków Śląskich, z. 4, Katowice 2011, s. 39-40 oraz Z. Jedynak, Ordunek Gorny...

${ }^{61}$ Tekst za: Codex Diplomaticus Silesiae, t. XX, red. K. Wutke, Breslau 1900, poz. 427, s. 59. 


\section{Pięćdzieśiąty Osmy Artikul.}

Że każdą sobotę szychtmistrz, huttmani, płoczkowie, rosztarze, lenszofnicy wszyscy schafarze, ktorzy w swey mocy robotniki maią, od każdego dwa halerza wziąć maiąm. Ci wszyscy przednicy od robotnikow przy płacy po dwu[ch] halerzach brać maią, a do zamknioney skrzinki albo pokładnice do żupnika włożyć, do ktorey on ÿ rada po kluczu mieć maią. A te pieniądze maią być dla ubogich niemocznych pachołkow albo na rzeczy pospolite dobre nałożyć, a każdy quartał [s], albo gdy czas przyidźie naszemu, żupnikowi a Radzie z tego poczet uczynićc ${ }^{6}$.

\section{Artykul 58}

Ci wszyscy szychmistrzowie ${ }^{63}$ lub hutnicy ${ }^{64}$, rozmieniacze $^{65}$, rostarze $^{66}$, lenszownicy ${ }^{67}$, wszyscy inni szafarze, mający pod sobą [pod swoją władzą - J.P.] robotników ${ }^{68}$, od każdego z nich powinni pobierać po 2 halerze ${ }^{69}$.

${ }^{62}$ Tekst za: Ordunek Górny - ustawa górnicza dla Górnego Ślaska z 1528 r., oprac. E. Kobzdaj, Wrocław - Warszawa - Kraków 1990.

${ }^{63}$ Niem. schichtmeister, co tłumaczy się jako „Szychmistrz” (Z. Malawski, T. Morawski, Niemiecko-polski popularny stownik górniczy, Katowice b.r.w., s. 133). Jak wskazano niemieckim słowniku górniczym szychmistrz to członek społeczności gwareckiej (niem. Ein Bedienter der Gewerkschaft) zajmujący się nadzorowaniem określonej grupy górników; J.C. Stössel, Bergmännisches Wörterbuch, Chemnitz 1778, s. 458. Nieco inną definicję wskazywał Eugeniusz Kobzdaj, akcentując, że do obowiązków szychmistrza należało ogólne kierowanie aspektami gospodarczymi działalności kopalni; Ordunek Górny - ustawa górnicza dla Górnego Ślaska z 1528 r., oprac. E. Kobzdaj, Wrocław - Warszawa - Kraków 1990, s. 52.

${ }^{64}$ Niem. huttleute. Eugeniusz Kobzdaj podaje, że Huttman po niemiecku ,znaczy tyle co sztygar lub kierownik techniczny kopalni” (Ordunek..., s. 50). W niemieckim słowniku górniczym z 1778 roku próżno szukać terminu „Huttman”, zawarto tam jednak definicję pojęcia Huttenarbeiter oznaczającą osobę, która zajmuje się oddzielaniem kruszcu od urobku (niem. find die Arbeiter, welche die Beschichtung der zu verschmelzenden Erze, das Schmelzen, abteriben, und was sonst nothig, verrichten; Wörterbuch..., s. 270). Wydaje się, że w odniesieniu do górnictwa kruszcowego, dla którego Ordunek Górny został wydany, termin Huttleute oznaczał raczej osoby pracujące przy wytapianiu rudy. Przyjąć można zatem tłumaczenie „hutnicy”.

${ }^{65}$ Niem. wescher, czyli płukacze, $\mathrm{tj}$. osoby rozdrabniające urobek w rzece (niem. welche die Theile eines Floßes trennen; Wörterbuch..., s. 597).

${ }^{66}$ Niem. röster. Kobzdaj podaje proste thumaczenie ,prażelnik rudy” (Ordunek..., s. 52), co jest zbieżne z definicją zawartą w niemieckim osiemnastowiecznym słowniku górniczym, zaliczającą rostarzy (niem. Rostläufer) w poczet pracowników huty.

${ }^{67}$ Sformułowanie lehenheuer pochodzi od niemieckiego „Lehn”, czyli potwierdzonego (uznanego) urobku (Wörterbuch..., s. 325). Chodzi w tym przypadku o górników opłacanych „od urobku", czyli otrzymujących wynagrodzenie w systemie akordowym.

${ }_{68}$ Pod pojęciem „robotnika” (niem. arbeiter) w Ordunku Górnym rozumiano ogół pracowników fizycznych. W tym znaczeniu termin „robotnik” występuje w szeregu innych przepisów Ordunku Górnego, np. w art. 61.

${ }^{69}$ Halerz to drobna moneta srebrna, bita od XIII wieku, nazwę wzięła od miasta Hall w Szwabii. 12 halerzy było równe 1 białemu groszowi śląskiemu, zaś 36 białych groszy śląskich to 1 floren. 
W każdą sobotę co tydzień szychtmistrzowie, hutnicy, lenszownicy, rozmieniacze, rostarze, którzy pod swoją władzą robotników mają, z wynagrodzenia każdego spośród robotników 2 halerze zabierać mają i do zamkniętej skrzyni lub skarbca u górmistrza ${ }^{70}$ włożyć, do której to skrzyni po jednym kluczu górmistrz oraz rada mieć powinni. Pieniądze te mają służyć na utrzymanie biednych chorych towarzyszy ${ }^{71}$ i na inne zwyczajne cele. W suche dni każdego kwartału lub kiedy czas tego wymaga, staroście górniczemu ${ }^{72}$, górmistrzowi i radzie rachunek $\mathrm{z}$ tego będą czynić ${ }^{73}$.

\section{ZAKRES PODMIOTOWY UBEZPIECZENIA - UBEZPIECZENI}

Omawiana regulacja art. 58 zakreśla katalog ubezpieczonych bardzo szeroko. Otóż obowiązek zapłaty składki obejmował wszystkich „robotników”, tj. osoby znajdujące zatrudnienie w górnictwie, niewykonujące jednak obowiązków kierowniczych. Kryterium dyferencjacji osób objętych przymusem ubezpieczeniowym była zatem wykonywana praca czy też powierzone obowiązki. Należy bowiem przyjąć, że wyróżnikiem poszczególnych funkcji górniczych, o których mowa w Ordunku, był określony zakres obowiązków, odmienny od tego, który należał do robotników (praca fizyczna pod cudzym kierownictwem). Przesłanek do takiej właśnie interpretacji dostarczało w szczególności sformułowanie

Por. J. Kuliszer, Powszechna historia gospodarcza średniowiecza i czasów nowożytnych, t. I, Warszawa 1961, s. 330.

${ }^{70} \mathrm{~W}$ literaturze polskojęzycznej funkcjonuje także określenie ,żupnik”. Wedle najogólniejszej definicji berckmeister (bergmeister) był to „urzędnik, faktycznie sprawujący jurysdykcję nad określonym obszarem" (niem. ist der Beamte, dem eigentlich die Gerichtsbarkeit in der ihm in der Revier; Wörterbuch..., s. 79). Górmistrz miał bardzo szerokie faktyczne kompetencje; „w rzeczywistości najważniejsze znaczenie dla górnictwa miał nie tyle starosta, a żupnik" (W. Zaleski, Dzieje górnictwa i hutnictwa na Górnym Śląsku do roku 1806, Madryt 1967, s. 30).

${ }^{71}$ Niem. Geselle. Precyzyjnie można to przetłumaczyć jako „członek społeczności górniczej” (niem. Gesellschaft - społeczność [górnicza]; F. Piestrak, Niemiecko-polski słownik górniczy, Katowice 1924, s. 139). Mając na względzie kontekst użycia tego sformułowania stwierdzić należy, iż używany przez Piernikarczyka zwrot „pachołkowie”, wywodzący się od dosłownego thumaczenia Geselle na „czeladnik”, nie jest prawidłowy. Beneficjentami ochrony ubezpieczeniowej byli bowiem wszyscy robotnicy górniczy opłacający składki, nie zaś jedynie pachołkowie czy czeladnicy, tj. osoby stojące najniżej w hierarchii górniczej. Termin „towarzysze” jest charakterystyczny dla art. 58 Ordunku Górnego, z czego można wywodzić, że do kategorii tej należeli beneficjenci ochrony zapewnianej przez kasę bracką.

${ }^{72}$ Niem. Berckhauptmann [Berghauptmann] - starosta górniczy (F. Piestrak, Niemiecko-polski słownik..., s. 40); „najwyższy sędzia w sprawach górniczych” (niem. der oberste Richter in Bergsachen; Wörterbuch..., s. 72). Był to najwyższy urzędnik górniczy, stojący na czele kopalń leżących we wszystkich górnośląskich posiadłościach margrabiego Jerzego Hohenzollerna; por. W. Zaleski, Dzieje górnictwa ..., s. 30 .

73 Tłumaczenie własne autora za: Codex Diplomaticus Silesiae, t. XX, red. K. Wutke, Breslau 1900, poz. 427 , s. 259. 
„ci wszyscy”74, po którym następuje wymienienie poszczególnych funkcji górniczych, z którymi związana była nadrzędność służbowa nad osobami wykonującymi pracę fizyczną (robotnikami).

Jak się wydaje, enumeracja zawarta w zdaniu pierwszym in principio art. 58 ma charakter przykładowy. Obok wymienionych w zdaniu pierwszym art. 58 szychtmistrzów, hutników, rozmieniaczy, prażelników oraz parobków opłacanych od urobku (lenszowników), wskazano także kategorię „wszelkich innych szafarzy, mających pod sobą robotników" "75. Można z tego wnosić, że jest to wyszczególnienie przykładowe, zaś czynnikiem decydującym o zakwalifikowaniu do jednej z dwóch grup było kryterium podporządkowania. Dokonując rozróżnienia w oparciu o kryteria zawarte w zdaniu pierwszym art. 58 można bowiem podzielić osoby trudniące się górnictwem na dwie grupy: robotników oraz osoby nadzorujące.

Cechą pierwszych było wykonywanie pracy podporządkowanej, pod nadzorem innego górnika, choćby nawet nie miał on przypisanej żadnej szczególnej funkcji ${ }^{76}$. Drugą grupę górników stanowili z kolei ci, którzy pod swoją władzą (nadzorem) mieli jakichś robotników. Kryterium decydującym dla oceny powstania przymusu ubezpieczeniowego danego górnika był zatem charakter wykonywanej przez niego pracy. Jeśli była to praca fizyczna, wykonywana pod czyimś kierownictwem (nadzorem), to osobę tę można zaliczyć do kategorii robotników w rozumieniu art. 58. Z kolei osoby, do zadań których należało nadzorowanie wykonywania pracy przez innych górników należały do drugiej grupy, bez względu na nazwę sprawowanej funkcji.

Odnosząc się do zakresu podmiotowego przymusu ubezpieczeniowego $\mathrm{z}$ art. 58 należy mieć na względzie, iż regulacje zawarte w omawianym akcie normatywnym skierowane były do ogółu osób trudniących się górnictwem, oczywiście w obszarze regulowanym mocą tegoż aktu, czyli w księstwach opolskim, raciborskim i karniowskim oraz w państwie bytomskim.

Dalsze dookreślenie katalogu ubezpieczonych następowało w przedostatnim zdaniu art. 58. Wskazano tam w sposób wyraźny, iż składki ubezpieczeniowe miały służyć zabezpieczeniu utrzymaniu „biednych chorych towarzyszy”. Pod pojęciem „towarzyszy”, jak się wydaje, należało rozumieć ogół górników opłacających składki na ubezpieczenie. Podstaw do takiej tezy dostarcza w szczególności zestawienie ze sobą sformułowania „ci wszyscy” ze wskazaniem górników „funkcyjnych”, uprawnionych do pobierania składek, z frazą „towa-

74 Niem. wie all.

75 Niem. allerlei schaffer, die unter sich arbeiter haben.

${ }^{76} \mathrm{Na}$ istnienie podgrupy osób niesprawujących żadnych szczególnych funkcji, lecz niebędących robotnikami, wskazuje w szczególności sformułowanie „wszelcy inni parobkowie, mający pod sobą (pod swoją władzą) robotników" (niem. allerlei schaffer, die unter sich arbeiter haben). 
rzysze", która poprzez brak dodatkowego dookreślenia wskazuje wszystkich płatników składek jako potencjalnie uprawnionych do otrzymywania świadczeń ubezpieczeniowych.

\section{PRZEDMIOT UBEZPIECZENIA}

Kolejnym elementem art. 58 zasługującym na skomentowanie jest kwestia przedmiotu ubezpieczenia. Wskazać przy tym należy, iż zinterpretowanie regulacji w zakresie przedmiotu ubezpieczenia powinno w konsekwencji ułatwić przypisanie ubezpieczeniu $\mathrm{z}$ art. 58 cech pozwalających na określenie go mianem protoplasty którejś ze współczesnych kategorii ubezpieczeń - ubezpieczeń gospodarczych lub społecznych ${ }^{77}$.

Jak wynika ze zdania drugiego art. 58, gromadzone pieniądze „mają być przeznaczane na utrzymanie biednych chorych towarzyszy i na inne zwyczajne cele" ${ }^{\text {"78 }}$. Jak wskazano wyżej, do grona ubezpieczonych zaliczony został ogół górników, wykonujących pracę podporządkowaną. Wydaje się, że dekodując z przytoczonego fragmentu art. $58 \mathrm{krąg}$ beneficjentów ubezpieczenia należy zwrócić uwagę na rozróżnienie terminologiczne pomiędzy ubezpieczonymi określonymi jako „robotnicy”79 a uprawnionymi z ubezpieczenia, którzy są określani jako „towarzysze" $"$.

Zakładając racjonalność prawodawców w osobach Jana i Jerzego należałoby stwierdzić, że ta dyferencjacja miała swoje uzasadnienie. Można przypuszczać, że rozróżnienie miało na celu podkreślenie wskazania jako beneficjentów grona szerszego niż tylko czynni robotnicy górniczy. Można bowiem przypuszczać, że osoba chora lub z przyczyn losowych (np. pożar domu) uboga, nie była już określana mianem „robotnika”, gdyż z pewnych względów nie była w danym momencie aktywna zawodowo. Jednakże chwilowy brak aktywności zawodowej, spowodowany określonymi czynnikami natury obiektywnej, nie prowadził do utraty statusu ubezpieczonego, przeciwnie - jeśli w momencie wystąpienia zdarzenia powodującego szkodę dana osoba posiadała status ubezpieczonego, to aktualizował się obowiązek wypłaty stosownego świadczenia.

${ }^{77} \mathrm{~W}$ tym także ubezpieczenia zdrowotnego, rozumianego jako rodzaj ubezpieczenia społecznego - por. I. Jędrasik-Jankowska, Pojęcie i konstrukcje prawne ubezpieczenia społecznego, Warszawa 2014, s. 27.

${ }^{78}$ Niem. und solch geld zu erhaltung der armen kranken gesellen und andern gemeinen nutz anwenden.

${ }^{79}$ Niem. arbeiter.

${ }^{80}$ Niem. gesellen. 
Z przytoczonego wyżej fragmentu zd. 2 art. 58 wynika, że katalog zdarzeń objętych ubezpieczeniem nie był zamknięty. Obok dwóch wypadków wskazanych expressis verbis (popadnięcie w biedę lub chorobę) podano także, ,inne zwyczajne cele" jako uzasadniające wypłatę świadczenia ze wspólnej kasy. W konsekwencji przyjąć należy, iż katalog zdarzeń ubezpieczeniowych był otwarty. Należały do niego zdarzenia różnego rodzaju - począwszy od zdarzeń o charakterze zdrowotnym (wskazana wprost choroba), po zdarzenia, które można zakwalifikować jako szkoda majątkowa (popadnięcie w ubóstwo). Podkreślić przy tym należy, iż otwarty charakter katalogu zdarzeń ubezpieczeniowych uzależniał udzielenie świadczenia ze wspólnej kasy od przesłanek o charakterze ocennym, tj. od zakwalifikowania przez dysponentów kasy danego zdarzenia jako ,innego zwyczajnego celu". Ze względu na brak źródeł nie wydaje się jednak możliwe dookreślenie kategorii „innych zwyczajnych celów” w rozumieniu art. 58. Wyznaczenie desygnatów tego katalogu, jak się wydaje, byłoby możliwe jedynie w oparciu o badania źródłowe w zakresie praktyki stosowania art. 58 przez dysponentów pieniędzy zgromadzonych w skrzyni u górmistrza.

W konsekwencji przyjąć należy, iż w art. 58 przyjęto szeroki katalog zdarzeń ubezpieczeniowych, uzasadniających uruchomienie wypłaty świadczenia. Generalnie przesłanki wypłaty można sprowadzić do prostej konstatacji, że dla przyjęcia odpowiedzialności i w konsekwencji wypłaty świadczenia wystarczające było objęcie danej osoby ochroną ubezpieczeniową w momencie wystąpienia zdarzenia ubezpieczeniowego. W razie stwierdzenia, że w dacie wystąpienia zdarzenia poszkodowany był objęty ubezpieczeniem należało dokonać weryfikacji negatywnej przesłanki odpowiedzialności w postaci niemożności przypisania zdarzeniu ubezpieczeniowemu charakteru choroby, ubóstwa lub innego zwyczajnego celu. Jeśli jednak można było wypadek zaliczyć do którejś z tych kategorii, świadczenie ubezpieczeniowe przysługiwało zgodnie z art. 58.

\section{PRZYMUS UBEZPIECZENIOWY I WYSOKOŚĆ SKŁADKI}

Ubezpieczenie, o którym mowa w art. 58, miało charakter przymusowy. Obligatoryjny charakter ubezpieczenia górników wynikał wyraźnie ze zdania drugiego art. 58, gdzie wskazano, że osoby obowiązane do pobierania składki ubezpieczeniowej „2 halerze zabierać mają i do zamkniętej skrzyni lub skarbca u górmistrza włożyć" "s1. Składka ubezpieczeniowa miała być pobierana z wynagrodzenia robotników co sobotę (art. 58 zd. 2 in principio). Dla przyjęcia, że dana osoba jest objęta przymusem ubezpieczeniowym wystarczająca była zatem przynależność do okre-

${ }^{81}$ Niem. 2 heller einnemen und in ein verschlossene lad oder buchs bei dem berckmeister einlegen. 
ślonej kategorii osób, tj. robotników górniczych wykonujących pracę w kopalni. Ze strony ubezpieczonego nie była wymagana jakakolwiek dodatkowa czynność dla potwierdzenia objęcia ubezpieczeniem, bowiem nawet składki były pobierane niezależnie od jego woli - w drodze potrącenia części wynagrodzenia w każdą sobotę.

Wysokość składki ubezpieczeniowej należy określić jako niezbyt wygórowaną. W stosunku tygodniowym z wypłat należnych poszczególnym robotnikom potrącano 2 halerze, tj. 1/6 grosza śląskiego ${ }^{82}$. Zestawiając tę kwotę $\mathrm{z}$ wynagrodzeniami podstawowymi górników, wskazanymi w art. 61, wysokość składki wydaje się być dość mało dolegliwa. Zwyczajny robotnik górniczy otrzymywał bowiem dniówkę w zasadniczej wysokości 21/2 grosza. Przyjmując przeciętnie sześciodniowy tydzień roboczy, tj. z niedzielą jako dniem wolnym, robotnik powinien był otrzymywać tygodniowe wynagrodzenie w wysokości 15 groszy, tj. 180 halerzy. Po odjęciu składki ubezpieczeniowej robotnikowi pozostawało zatem 178 halerzy. W stosunku procentowym składka wynosiła niewiele ponad $1 \%$ tygodniowego wynagrodzenia.

Niemniej jednak obecnie w literaturze przedmiotu wskazuje się, iż w odczuciu robotników górniczych ich wynagrodzenia były niskie, zaś nałożone na nich obciążenia zbyt dolegliwe. Dnia 8 sierpnia 1534 roku, a więc mniej niż dekadę po wydaniu Ordunku Górnego, w Tarnowskich Górach doszło do poważnych rozruchów. W dniu wypłaty górnicy, uprzednio uzbroiwszy się w kilofy, zaatakowali urząd górniczy oraz zdewastowali zabudowania kopalniane, w tym także sprzęt odwadniający i inne niezbędne urządzenia. Wśród głównych problemów, które pchnęły górników do tak radykalnych kroków wskazuje się kwestię czasu pracy (praca w niedziele i święta) oraz wysokość płac i sposób ich naliczania. Co jednak znamienne, wśród innych powodów niezadowolenia górników podaje się, że „górnicy protestowali także przeciwko niewłaściwemu wykorzystaniu pieniędzy z kasy brackiej" ${ }^{83}$. W rezultacie przypuszczać można, iż obciążenia fiskalne górników były w ich ocenie znaczne, zaś dołożenie mocą art. 58 kolejnego obowiązku uszczuplenia swoich dochodów nie spotkało się z aprobatą braci górniczej.

\section{POBÓR SKŁADKI UBEZPIECZENIOWEJ I JEJ ROZLICZANIE}

Co znamienne, obowiązek pobierania składki ubezpieczeniowej ciążył na wskazanych wcześniej osobach pełniących funkcje kierownicze w kopalniach i wszystkich innych, którzy pod swoją władzą (nadzorem) mieli jakichś robot-

${ }^{82} 1$ halerz był równy 1/12 grosza śląskiego. Por. E. Kobzdaj, Ordunek gorny..., s. 17.

${ }^{83}$ K. Martin, Zmiany w sytuacji społeczno-gospodarczej górników i gwarków w górnictwie rud metali w Europie Środkowej od XIII do XVI w. [w:] P.P. Zagożdżon, M. Madziarz, Dzieje górnictwa - element europejskiego dziedzictwa kultury, t. 2, Wrocław 2009, s. 215. 
ników. Składki nie były zatem pobierane bezpośrednio przez urzędnika działającego z upoważnienia uprawnionego do prowadzenia eksploatacji górniczej, lecz przez samych górników. Składki pobierali oczywiście nie górnicy robotnicy, lecz ci spośród braci górniczej, którzy zajmowali odpowiedzialne funkcje, a przynajmniej byli przełożonymi robotników górniczych.

Składki nie były jednak gromadzone przez samych górników, lecz przez górmistrza. Jak wynikało z treści przepisu art. 2 Ordunku górmistrz ${ }^{84}$ był drugim co do rangi urzędnikiem górniczym, zaraz po staroście górniczym ${ }^{85}$, w przeciwieństwie jednak do niego należącym do kadry kierowniczej kopalni. Jak się wydaje, obowiązek złożenia składek ubezpieczeniowych u górmistrza podyktowany był nie tylko chęcią zapewnienia ich bezpieczeństwa oraz oparcia się o autorytet osoby sprawującej funkcję górmistrza i godność jego urzędu, ale miał również na celu zapewnienie udziału czynnika urzędowego w ubezpieczeniu robotników górniczych. Udział czynnika publicznego w gospodarowaniu zgromadzonymi składkami oraz nadzorowaniu ich rozdziałem był ograniczony. Przesłanek do takiej interpretacji dostarczał bowiem zd. 3 art. 58, które mówiło, że „w suche dni każdego kwartału lub kiedy okoliczności (czas) tego wymagają, staroście górniczemu, górmistrzowi i radzie rachunek $\mathrm{z}$ tego [z wydatkowania zgromadzonych składek ubezpieczeniowych - J.P.] będą czynić" ${ }^{86}$.

Udział czynnika publicznego $\mathrm{w}$ obligatoryjnym ubezpieczeniu robotników górniczych był zatem ograniczony właściwie do dwóch elementów. Po pierwsze, jak wskazano wyżej, składki ubezpieczeniowe były gromadzone przez górmistrza. Po wtóre, górmistrz razem ze starostą górniczym brali udział w dokonywaniu kwartalnych rozliczeń z tytułu zgromadzonych składek oraz świadczeń wypłaconych z ubezpieczenia. To ostatnie zadanie urzędnicy wykonywać mieli jednak wespół z tarnogórską radą miejską. W konsekwencji przyjąć należy, iż wydatkowanie środków ze wspólnej kasy zostało poddane kontroli podmiotów o trojakiej proweniencji. Po pierwsze uprawnionym do dokonania kontroli był urzędnik działający z upoważnienia władcy w osobie starosty górniczego. Po drugie podmiotem, któremu należało zdać rachunek z wydatkowania środków pochodzących ze składek był górmistrz, czyli najwyższy urzędnik górniczy, będący przedstawicielem właściciela kopalni.

Wreszcie sposób wydatkowania wspólnych środków winien był zostać poddany ocenie rady miasta Tarnowskie Góry, tj. samorządowego ciała obieralnego w mieście, którego status wolnego miasta górniczego, jak wskazano wyżej, ściśle

\footnotetext{
${ }^{84}$ Niem. bergmeister.

${ }^{85}$ Niem. berghauptmann.

${ }^{86} \mathrm{Niem}$. alle quatember oder wenn es die zeit erfordert, unserm berckhauptmann berckmeister und ratleuten davon rechnung tuen.
} 
wiązał się z prowadzoną w jego rejonie działalnością górniczą. Podkreślić jednak należy, iż co do zasady dysponentami sum zgromadzonych w skrzyni pozostawali górmistrz oraz rada, bez udziału starosty górniczego. Wydaje się zatem, iż element publicznoprawny w odniesieniu do składek ubezpieczeniowych zgromadzonych przez górników występował jedynie w odniesieniu do nadzoru nad prawidłowością wydatkowania tychże pieniędzy. Reprezentujący władcę starosta górniczy nie był uprawniony do współdecydowania o sposobach rozdysponowania zebranych funduszy. Do tego byli uprawnieni jedynie posiadacze klucza do skrzyni, a to górmistrz i rada, czyli podmioty, które były przedstawicielami bądź to samorządowej korporacji (rada), bądź też reprezentowały właściciela (górmistrz) ${ }^{87}$. Należy wyraźnie zaznaczyć rozróżnienie między współdecydowaniem o wydatkowaniu środków zgromadzonych w skrzyni górmistrza, inkorporowanym przez posiadanie klucza do skrzyni, od prawa do udziału w czynnościach kontrolnych.

Podkreślić trzeba także, iż nadzór nad wydatkowaniem składek ubezpieczeniowych nie został obwarowany jakimikolwiek normami, które wiązałyby z kontrolą uprawnienia władcze. Oznacza to, że przedstawiciel pana feudalnego, czyli starosta górniczy, pozbawiony był realnego wpływu na funkcjonowanie ubezpieczeń górniczych i wydatkowanie gromadzonych środków. Kompetencje te należały wyłącznie do depozytariuszy kluczy, czyli do górmistrza oraz do rady. W konsekwencji stwierdzić należy, iż udział czynnika publicznoprawnego w systemie ubezpieczeń opartych na art. 58 był minimalny, ograniczony wyłącznie do uprawnienia do udziału w kwartalnych czynnościach sprawozdawczo-nadzorczych. Treść art. 58 nie pozwala na zidentyfikowanie jakichkolwiek kompetencji władczych związanych z nadzorem, w związku z czym przyjąć trzeba, że starosta górniczy nie był w nie wyposażony.

Mając na względzie powyższe ustalenia nie sposób zgodzić się z prezentowanymi dawniej poglądami, jakoby „zarząd kasy spoczywał jednak w rękach urzędników, co sprawiało, że traciła ona charakter samorządowy, przekształcając się w narzędzie wyzysku robotników drogą przerzucenia na ich barki wszelkich świadczeń socjalnych"88. Środki zgromadzone przez samych górników pozostawały we wspólnym zarządzie górmistrza oraz rady, stanowiącej przecież obieralne przedstawicielstwo mieszkańców Tarnowskich Gór. Oznacza to, że zgromadzone środki były zarządzane co najmniej przy współudziale czynnika samorządowego. Jeśli zaś chodzi o górmistrza, to nadmienić należy, iż co prawda można zakwalifi-

87 Właścicielem kopalni nie musiał być bowiem jedynie pan feudalny. Współwłaścicielami mogli być bowiem sami górnicy w osobach „gwarków”, czyli górnikach uczestniczących w zyskach (od niem. Gewerke - współudziałowiec w produkcji). Por. Z. Jedynak, Ordynacja górnicza (Ordunek Górny) jako podstawa rozwoju Tarnowskich Gór, „Montes Tarnovicensis” 2008, nr 31-32.

${ }^{88}$ D. Molenda, Górnictwo kruszcowe..., s. 319. 
kować go do kategorii „urzędników”, lecz z tym zastrzeżeniem, że był to urzędnik reprezentujący właściciela kopalni, nie zaś władcę.

Wydaje się, iż niezasadny jest także zarzut rzekomego ,wyzysku” robotników górniczych poprzez ubezpieczenia oparte o art. 58. Podkreślić bowiem należy, iż postulaty wprowadzenia systemów zabezpieczenia robotników na wypadek choroby czy kalectwa zostały zrealizowane na obszarze Śląska dopiero w latach osiemdziesiątych XIX wieku, tj. trzy i pół wieku później ${ }^{89}$. Wydaje się zatem, iż ubezpieczenie wprowadzone mocą art. 58 było instytucją bardzo nowoczesną jak na swoje czasy i znacznie wyprzedzało postulaty ruchu robotniczego, które wykrystalizowały się dopiero w epoce industrialnej.

\section{PODSUMOWANIE}

Kończąc rozważania w przedmiocie ubezpieczenia opartego na art. 58, można wskazać kilka charakteryzujących je cech. Po pierwsze omawiane ubezpieczenie było powszechne w odniesieniu do robotników górniczych. Obejmowało ono bowiem wszystkich robotników górniczych, tj. osoby wykonujące pracę podporządkowaną w kopalniach. Z tym przymiotem wiąże się ściśle kolejny wyróżnik. Ubezpieczenia te miały charakter przymusowy. Z przynależnością do grupy robotników górniczych i wykonywaniem pracy wiązał się obowiązek zapłaty składki ubezpieczeniowej. Składka była pobierana niezależnie od woli ubezpieczonego. Jak się wydaje, przedmiotowe ubezpieczenie dotyczyło także sytuacji wykraczających poza przypadki dotyczące stricte utraty zdrowia i obejmowało swoim zakresem sytuacje pogorszenia sytuacji materialnej i zdolności zarobkowych wskutek innych zdarzeń niż tylko te związane z utratą zdrowia.

Składka ubezpieczeniowa ustalona była na raczej niezbyt wygórowanym poziomie. Jej pobieranie należało do górników funkcyjnych, zaś rozdzielaniem świadczeń pośród uprawnionych zajmowała się tarnogórska rada miejska wespół z górmistrzem. Podmiotom tym oraz reprezentującemu władcę staroście górniczemu miały być kwartalnie składane sprawozdania $\mathrm{z}$ wydatkowania zgromadzonych środków.

Zaprezentowane wyżej konkluzje mogą pozwolić na dokonanie kwalifikacji ubezpieczenia opartego na art. 58 jako ubezpieczenia o charakterze gospodarczym lub społecznym. Wśród cech rozróżniających te kategorie wskazać w szczególności należy na różny przedmiot tych ubezpieczeń oraz przymus ubezpieczenia. Przedmiotem ubezpieczenia gospodarczego jest życie, mienie lub zdrowie ubez-

${ }^{89}$ S. Płaza, Historia prawa $w$ Polsce na tle porównawczym. Zarys wykładu, cz. 2, Kraków 1994, s. 90. 
pieczonego ${ }^{90}$, zaś przedmiotem ubezpieczenia społecznego jest ochrona od takich ryzyk jak choroba, inwalidztwo, starość czy śmierć ${ }^{1}$. Jeśli zaś chodzi o możliwość przystąpienia do ubezpieczenia gospodarczego, to co do zasady polega ono na dobrowolności, wyjątkowo zaś może zostać wprowadzony obowiązek ubezpieczenia. Tymczasem ubezpieczenia społeczne oparte są na zasadzie przymusu' ${ }^{92}$. Podkreślić jednak należy, iż w perspektywie historycznej granice pomiędzy ubezpieczeniami gospodarczymi a społecznymi nie zawsze są wyraźnie widoczne ${ }^{93}$, stąd też zakwalifikowanie ubezpieczenia z art. 58 do którejś z tych kategorii może nosić znamiona pewnego uproszczenia i uwydatnienia wybranych cech.

Przy zastosowaniu opisanych wyżej kryteriów dyferencjacji, zaczerpniętych z dorobku współczesnej doktryny, trudno o jednoznaczne zakwalifikowanie ubezpieczeń z art. 58 do kategorii ubezpieczeń gospodarczych lub społecznych. Zdefiniowanie przedmiotu tegoż ubezpieczenia nie jest łatwe, gdyż art. 58 pozostawia katalog ryzyk ubezpieczeniowych otwartym. Oznacza to, że omawiane ubezpieczenie chroniło górników od zdarzeń ubezpieczeniowych charakterystycznych dla ubezpieczeń społecznych (np. kalectwo), ale również od bliżej niesprecyzowanego katalogu innych zdarzeń, uznawanych w konkretnych okolicznościach za uzasadniające wypłatę świadczenia. Przedmiot ubezpieczenia z art. 58 nie pozwala zatem na jednoznaczne zakwalifikowanie go jako ubezpieczenia społecznego lub gospodarczego.

W przypadku przymusu ubezpieczeniowego sytuacja wygląda podobnie. Otóż omawiane ubezpieczenie było obowiązkowe, jednakże tylko w odniesieniu do konkretnej grupy osób (robotników górniczych). Nie miało ono charakteru powszechnego, tj. obejmującego wszystkich pracujących. Zgodnie z wprowadzającym obowiązek ubezpieczenia art. 58 ubezpieczenie to ograniczało się bowiem do precyzyjnie określonej kategorii robotników górniczych. Brak powszechnego charakteru z jednej strony, z drugiej zaś obowiązkowy charakter, także utrudniają dokonanie kwalifikacji omawianego ubezpieczenia jako gospodarczego lub społecznego.

Pewnego ułatwienia dla kwalifikacji ubezpieczenia $\mathrm{z}$ art. 58 dostarcza jednak dorobek międzywojennej doktryny prawa ubezpieczeń. Jak wskazywał Jan Łazowski „o ile celem ubezpieczenia prywatnego jest ochrona jednostek (...) niezależnie od ich roli i sytuacji społecznej, celem ubezpieczenia społecznego jest ochrona jednostek jako członków określonej klasy społecznej przed degra-

90 I. Jędrasik-Jankowska, Pojęcie i konstrukcje..., s. 29.

${ }_{91}$ M. Olszewska, Zakres przedmiotowy ubezpieczenia społecznego [w:] Ubezpieczenie spoteczne-dawniej i dziś, Wrocław 2013, s. 27.

92 I. Jędrasik-Jankowska, Pojęcie i konstrukcje..., s. 29-30.

93 M. Orlicki, Ubezpieczenia obowiazkowe, Warszawa 2011, s. 33. 
dacją społeczną"94. Dokonując zestawienia opisanych wyżej cech ubezpieczenia opartego na art. 58 z definicją ubezpieczeń społecznych w ujęciu Łazowskiego stwierdzić należy, iż omawiane ubezpieczenie nie miało charakteru ubezpieczenia społecznego. Posługując się argumentem a contrario należy w konsekwencji stwierdzić, iż omawiane ubezpieczenie należałoby zakwalifikować raczej jako ubezpieczenie o charakterze gospodarczym.

Ubezpieczenia górników, choć być może do ich powstania przyczyniło się samoorganizowanie się robotników górniczych, pozbawione było władczego elementu w zarządzaniu gromadzonymi składkami. Co więcej, ubezpieczenie to nie miało, jak się wydaje, na celu zapewnienia ochrony przed ryzykami społecznymi. Chodziło bowiem o ryzyka natury raczej ekonomicznej, jak utrata zdolności zarobkowych wskutek kalectwa czy też popadnięcie w nędzę w następstwie nieszczęśliwych wypadków. Biorąc zaś pod uwagę cel ubezpieczenia gospodarczego, którym wedle współczesnych definicji jest „ubezpieczenie strat finansowych związanych z realizacją najrozmaitszych typów ryzyka" ${ }^{95}$ ubezpieczenie $\mathrm{z}$ art. 58 zdaje się być bliższe ubezpieczeniu gospodarczemu niż społecznemu.

Ze wzglądu zaś na brak udziału władcy w gromadzeniu i dysponowaniu składkami ubezpieczeniowymi należy wskazać, iż ubezpieczenie oparte na art. 58 miało charakter ubezpieczenia wzajemnego. Powstałą tzw. „kasę bracką” należałoby zakwalifikować zaś jako protoplastę towarzystwa ubezpieczeń wzajemnych. Jak wskazuje się współcześnie „przystępując do ubezpieczenia wzajemnego, podmiot ubezpieczający przenosi ryzyko na ubezpieczyciela, którego jest członkiem, a w rezultacie przenosi również część ryzyka na własną osobę. Towarzystwo ubezpieczeń wzajemnych jest więc prawnie odrębnym podmiotem, jednak z chwilą zawarcia umowy ubezpieczenia w sensie gospodarczym podmioty wzajemnie się zabezpieczają"96. Jako że omawiane ubezpieczenie miało charakter obowiązkowy, wykonywanie pracy jako robotnik górniczy wiązało się z przymusem ubezpieczeniowym. Nie ulega zaś wątpliwości, iż wszyscy spośród robotników górniczych byli zarówno ubezpieczającymi, jak i ubezpieczonymi. Uczestnicząc $\mathrm{w}$ ubezpieczeniu dzielili między siebie ryzyka, ponosząc jednocześnie równe składki ubezpieczeniowe na rzecz wspólnej kasy.

A zatem ubezpieczenie oparte na art. 58 można zakwalifikować raczej jako przykład wczesnego ubezpieczenia o charakterze gospodarczym niż ubezpieczenia społecznego.

94 J. Łazowski, Wstęp do nauki o ubezpieczeniach, Warszawa 1934, s. 23.

95 W. Uruszczak, Umowy w zakresie ubezpieczeń [w:] S. Włodyka (red.), Prawo umów w obrocie gospodarczym, Warszawa 2001, s. 1024.

${ }_{96}$ M. Kamiński, Ubezpieczenia wzajemne a ubezpieczenia komercyjne, „Rozprawy ubezpieczeniowe" 2013, z. 15, s. 101. 


\title{
ARTICLE 58 OF THE MINING REGULATION (POLISH “ORDUNEK GÓRNY”) AND THE BEGINNING OF INSURANCE IN SILESIA
}

\begin{abstract}
The purpose of this article is to analyse the legal nature of insurance established by article 58 of the Mining Regulation of 1528. This regulation was issued by Jan II Opolski and Georg von Hohenzollern-Ansbach. One of its articles was dedicated to the issue of insurance for miners. Article 58 stipulated that a certain part of a miner's weekly wage was collected and stored in a chest. This money was accumulated and subsequently allocated to defray the needs of, among others, ill and crippled miners. Moreover, the paper includes a translation of article 58 and it briefly presents the literature pertaining to the Mining Regulation of 1528 .
\end{abstract}

\section{ARTICLE 58 D'ORDUNEK GORNY [L'ORDONNANCE MINIERE] DONNANT LE DEBUT DE L'ASSURANCE MINIERE EN SILESIE}

\section{Resumé}

Cet article est consacré à l'analyse de la nature juridique de l'assurance établie par l'article 58 de l'Ordonnance minière de 1528, rendue par Jean II d'Opole et Georges de Brandebourg-Ansbach. L'un de ses articles était consacré à l'assurance minière. L'article 58 prévoyait qu'une partie de la rémunération hebdomadaire serait prélevée et stockée dans un coffre. L'argent ainsi collecté était utilisé pour satisfaire les besoins, entre autres, des mineurs malades et handicapés. En outre, notre étude comprend la traduction de l'article 58 et présente brièvement les publications faisant référence à l'Ordonnance minière de 1528 